\title{
Effects of Biogas Substrate Recirculation on Methane Yield and Efficiency of a Liquid-Manure-Based Biogas Plant
}

\author{
Frauke P. C. Müller *, Gerd-Christian Maack and Wolfgang Buescher \\ Institute of Agricultural Engineering, Livestock Technology, Rheinische Friedrich-Wilhelms-Universität Bonn, \\ Nussallee 5, 53115 Bonn, Germany; c.maack@uni-bonn.de (G.-C.M.); buescher@uni-bonn.de (W.B.) \\ * Correspondence: Frauke-m@gmx.de; Tel.: +49-157-7258-6548; Fax: +49-228-73-2596
}

Academic Editor: Ola Eriksson

Received: 7 December 2016; Accepted: 3 March 2017; Published: 8 March 2017

\begin{abstract}
Biogas plants are the most complex systems and are heavily studied in the field of renewable energy. A biogas system is mainly influenced by biological and technical parameters that strongly interact with each other. One recommended practice when operating a biogas plant is the recirculation of the substrate from the second fermenter into the first fermenter, which extends the recirculation amount (RA) and, in turn, the recirculation rate (RR). This technique should be applied to support and secure the biogas process. In this investigation, the RA was varied, starting with the recommended "best practice" of $10.0 \mathrm{~m}^{3} / \mathrm{d}$ (RR 40\%). Every ten days, the RA was reduced in steps of $1.5 \mathrm{~m}^{3} / \mathrm{d}$, with $5.5 \mathrm{~m}^{3} / \mathrm{d}$ (RR $27 \%$ ) being the final value. The basic question to be addressed concerns to what extent the RR influences the methane yield and thereby influence the efficiency of a manure-based biogas plant in practice. Diverting the "best practice" to a RR of $27 \%$ stabilised the fermentation process and lead to significantly higher methane yields with smaller standard deviations. In addition, with a reduced RR, the standard optimal acid concentration within the biogas substrate was approximately reached.
\end{abstract}

Keywords: biogas; recirculation; hydraulic retention time (HRT); organic loading rate (OLR); methane output

\section{Introduction}

In today's society and economy, there is high acceptance of biogas as a green energy resource because of increasingly energy-demanding lifestyles [1] and dwindling fossil resources. Therefore, the use of biogas as a renewable energy source based on energy crops and organic residual materials is of high importance [2], even in the agricultural sector. In addition, biogas technology has been refined through many studies over the last few years. Two main key levers of biogas research can be distinguished: the understanding of microbiological activity and function and the optimization of the engineering performance.

The type of supply and the fermentation temperature are two of the main technical aspects of concern in a biogas plant. Most biogas plants are mainly fed with energy crops and a small amount of manure.

Energy crops, in contrast to manure, have a higher biogas potential, and their production is not coupled with animal farms [1]. However, manure, as by-product of livestock farms, is a central element in the concept of cascaded utilization because crops are not only used as an energy source. Livestock manure also helps to control the stability of the fermentation process [3]. In a first step, they serve as animal feed. They then serve as a substrate for a biogas plant in the second energy level. Even in Germany, biogas plants that are fed with a high percentage of manure, namely, up to $80 \%$ and $100 \%$, 
have become a focus of industry and practice because of special support produced by the German Renewably Energy Act of 2012 (EEG). The EEG facilitates the development of renewable energy to support electricity production from sustainable sources and guarantees a fixed feed-in remuneration for the producer.

Therefore, even livestock farms may be able to invest in the biogas sector. The production limit is $75 \mathrm{~kW}$ of electrical power. In Germany, the resulting type of biogas plant is called a "small biogas plant". This categorization is special for Germany and was defined by the amendment of the Renewable Energies Act in 2012 (EEG).

In terms of fermentation temperature, only two variations are used in practice. Most biogas plants operate at the mesophilic level $\left(30\right.$ to $40^{\circ} \mathrm{C}$ ) because the thermophilic range $\left(50\right.$ to $\left.55^{\circ} \mathrm{C}\right)$, where the digestion rate is higher because of better substrate accessibility and the promotion of the decomposition of organic matter [4], has lower process stability compared to mesophilic fermentation [5]. In addition, thermophilic biogas plants have a less complex biologic community compared to mesophilic systems [6]. Thus the thermophilic fermentation is characterized by a higher efficiency in different organic loading rates (OLR's) $[7,8]$.

The synthesis of biogas relies on a four-step process: first hydrolysis, followed by acidogenesis, acetogenesis and methanogenesis. In the hydrolysis step, complex compounds such as carbohydrates, proteins and fats are split into simple organic compounds. The hydrolysis further has a directional effect on the efficiency of the anaerobic fermentation [9]. During the acidogenesis, the intermediates formed are converted into precursor substances of biogas. In the third step, i.e., the acetogenesis, the intermediate products are converted into biogas precursor substances by acetogenic bacteria. In the final step, i.e., the methanogenesis, methane-forming bacteria convert acetic acid, carbon dioxide and hydrogen into biogas. Every step strongly depends on various (biological as well as technical) parameters such as temperature, $\mathrm{pH}$, dry matter $(\mathrm{DM})$ and organic dry matter (oDM) content, organic loading rate (OLR), hydraulic retention time (HRT), and acid spectrum $[2,10,11]$. The recirculation rate (RR) can be defined as a technical parameter. This rate describes the removal of the substrate of fermented biogas to the beginning of the biogas process as a proportion of the input of fresh substrate. Various positive effects can be achieved by varying the RR. The liquefaction and inoculation of the fresh biogas substrate and the stabilisation of biogas synthesis are three of the main factors in the process. Previous studies have highlighted the fact that varying the recirculation amount (RA) can be used to optimize biogas production $[12,13]$. This was again confirmed in many scientific works in the last thirty years, where high OLR (affected by an increased RR) leads to increased methane output [14-18].

Various factors, such as the accumulation of organic and inorganic ingredients $[19,20]$, the dilution of the biogas substrate leading to a stable $\mathrm{pH}$ value [21], as well as the stimulation of microorganisms [22], such as increased support of hydrogenothrophic methanogens [19], may be able to explain this effect.

By taking a holistic view of the biogas system, this investigation considers both biological as well as technical factors. The basic question concerns to what extent the RRs influence the methane yield and thus the efficiencies of a manure-based biogas plant. Moreover, there is the question of which biological parameters are affected by the RRs. Finally, can the RR be used as the controlling mechanism to provoke a different stabilizing effect on the process?

\section{Material and Methods}

The investigated biogas system is located at a dairy farm, with a current stocking of 140 dairy cows and 140 female breeding cows (LU 220) that produce on average $8000 \mathrm{~kg}$ of milk per cow per year, and belongs to the category of "small biogas plants". The electrical power output is $75 \mathrm{~kW}$. The fermenter is designed as a plug-flow digester with a capacity of $120 \mathrm{~m}^{3}$ (Figure 1). 


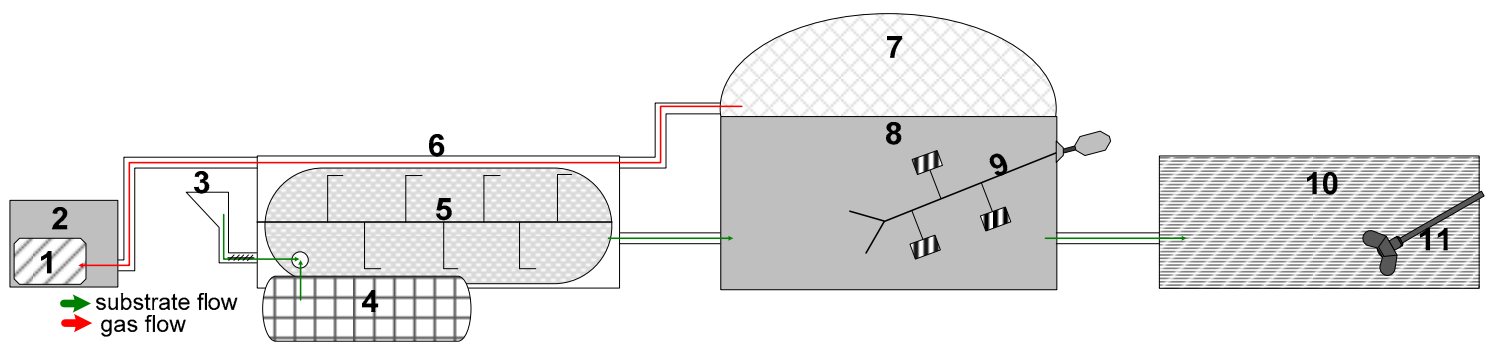

Figure 1. "Functional elements" of the investigated biogas plant. 1: CHP; 2: Control room; 3: solids fedders 4: Fermenter dump (slurry); 5: Agiator; 6: Fermenter; 7: Gas storage; 8: Secondary fermenter; 9: Paddle-giant; 10: Final storage; 11: Agiator.

Connected to this fermenter is a second fermenter designed as a classic round tank with a gas-tight cover and a $2000 \mathrm{~m}^{3}$ capacity. The space under the gas-tight cover serves as an integrated gas storage volume, from which the combined heat and power station (CHP) is supplied with biogas by pipelines. Within the storage volume, the biogas of the first and second fermenter is initiated. The system operates in the thermophilic range $\left(50\right.$ to $\left.55^{\circ} \mathrm{C}\right)$ and was put into service in October 2012. The present investigation was performed in the summer of 2013. The biogas plant is fed daily with $15 \mathrm{~m}^{3}$ of fresh substrate consisting of $93 \%$ slurry and $7 \%$ energy crops (corn silage and grain debris). The resulting substrate mix has a dry matter content of $11.1 \%$ (oDM: $5.6 \%)$.

\subsection{Recirculation of the Biogas Substrate}

The substrate from the second fermenter can be recirculated into the first fermenter within the biogas plant. The retention time of the biogas substrate within the biogas system is approximately 150 days. For the first 10-12 days, the biogas substrate remains in the first fermenter. As a result, the recirculated substrate from the second fermenter is a mixture of fermented substrate that ranges from 10 to 150 days old and includes microorganisms from every step of biogas synthesis.

For this investigation, four different recirculation amounts (RAs) were examined. As the first step, the recommend "best practice" (RA: $10 \mathrm{~m}^{3} / \mathrm{d}$; RR 40\%) was applied. Over an experimental period of 40 days, the recirculation was reduced to a minimum of $5.5 \mathrm{~m}^{3} / \mathrm{d}$ in steps of $1.5 \mathrm{~m}^{3} / \mathrm{d}$. Every rate was used for 10 days to allow the microorganisms in the biogas substrate sufficient time for an acclimatation phase and exhibit a visible reaction to the different RAs. After 10 days of one recirculation variation, samples of the biogas substrate were taken from the first fermenter. Every sample was sent to an external accredited laboratory for analysis. The acid contents were determined by an external laboratory using gas chromatography (in-house method). The $\mathrm{pH}$ value was analysed by EN 12176:1998 [23], DM by EN 12880:2000 [24] and oDM by EN 12879:2000 [25]. The methane content was documented every hour using the "BioBasic" analysis section by Fresenius Umwelttechnik GmbH (Herten, Germany). In Table 1, the experimental details are listed. Through a comparison of the theoretical total substrate input $\left(\mathrm{S}_{\mathrm{T}}\right)$ (standard value for daily feeding) and the actual feedstock (according to business book of the biogas plant, the calculated real fed quantities), it could be demonstrated that the experimental conditions were nearly 100 percent maintained.

Table 1. Input volumes of fresh substrate $\left(S_{F}\right)$ and recirculated substrate $\left(S_{R}\right)$.

\begin{tabular}{|c|c|c|c|c|c|}
\hline \multirow{2}{*}{$\begin{array}{c}\mathrm{RA}\left(\mathrm{S}_{\mathrm{R}}\right) \\
\mathrm{m}^{3} / \mathrm{d}\end{array}$} & \multirow{2}{*}{$\begin{array}{l}\text { Percentage of Fermenter } \\
\quad \text { Volume }\left(120 \mathrm{~m}^{3}\right)\end{array}$} & \multirow{2}{*}{$\begin{array}{l}\text { Fresh Substrate } \\
\qquad\left(\mathrm{S}_{\mathrm{F}}\right) \mathrm{m}^{3} / \mathrm{d}\end{array}$} & \multicolumn{2}{|c|}{ Total Substrate Input $\left(\mathrm{S}_{\mathrm{T}}\right) \mathrm{m}^{3} / \mathrm{d}$} & \multirow{2}{*}{$\begin{array}{l}\text { RR Ratio } \\
\text { of } S_{R} \text { to } S_{T}\end{array}$} \\
\hline & & & Theoretical & In Practice & \\
\hline 10.0 & $8 \%$ & 15.0 & 25.0 & 24.8 & $40 \%$ \\
\hline 8.5 & $7 \%$ & 15.0 & 23.5 & 23.7 & $36 \%$ \\
\hline 7.0 & $6 \%$ & 15.0 & 22.0 & 22.3 & $32 \%$ \\
\hline 5.5 & $5 \%$ & 15.0 & 20.5 & 20.6 & $27 \%$ \\
\hline
\end{tabular}


The RA in proportion to the total substrate input (RR) is approximately $40 \%$ in the first RA step and decreased to $27 \%$ in the final step (RA: $5.5 \mathrm{~m}^{3} / \mathrm{d}$ ) of the investigation. To better compare the various types of biogas plants, the RR was used as the parameter for the following analyses.

\subsection{Calculation of Organic Loading Rate And Hydraulic Retention Time}

The OLR describes the duration that the substrate remains in the fermenter until discharge and is expressed as $\left[\mathrm{kg} \cdot \mathrm{VS} \cdot \mathrm{m}^{3} \cdot \mathrm{d}^{-1}\right]$. The calculation of the OLR was performed using the following equation (based on [26]):

$$
O L R=\frac{\dot{m} \times c}{V_{R} \times 100}\left[\mathrm{~kg} \cdot \mathrm{VS} \cdot \mathrm{m}^{-3} \cdot \mathrm{d}^{-1}\right]
$$

In Equation (1) OLR is the organic loading rate, $\dot{m}$ the amount of substrate added per unit time $(\mathrm{kg} / \mathrm{d}) ; c$ the concentration of organic matter, VS are the volatile solids (\%VS) and $V_{R}$ is the reactor volume $\left(\mathrm{m}^{3}\right)$.

The HRT is calculated in days and is the ratio of the reactor volume $\left(V_{R}\right)$ to the volume of fresh substrate added daily $(\dot{V})[26]$ :

$$
H R T=\frac{V_{R}}{\dot{V}}[\mathrm{~d}]
$$

where HRT is the hydraulic retention time, $V_{R}$ the reactor volume $\left(\mathrm{m}^{3}\right)$, and $\dot{V}$ is the volume of substrate added daily $\left(\mathrm{m}^{3}\right)$.

The parameters OLR and HRT strongly interacted with each other. $\mathrm{S}_{\mathrm{T}}$ decreased with decreasing RA during the investigation. Thus, it can be assumed that a minimization of the OLR can be observed in parallel. Moreover, HRT should concurrently increase because the substrate can remain in the first fermenter for a longer duration.

\section{Results and Discussion}

The reduction in the RA of digested substrate from the second fermenter to the first fermenter affected the biological structure and methane output. RAs of 10.0, 8.5, 7.0 and $5.5 \mathrm{~m}^{3} / \mathrm{d}$ were compared using the technical parameters OLR and HRT; methane output and biological parameters such as $\mathrm{pH}$, dry matter (DM) and organic dry matter (oDM) content; and butyric, acetic and propionic acid concentrations.

The calculated OLR and HRT confirm these values to be the most important parameters describing the functionality of the biogas system with regard to the economic viability of the optimized substrate reduction. The OLR increased (Figure 2) with decreasing RA, and the HRT (Figure 2) decreased during the investigated timeframe. A significant negative correlation of $R=-0.912$ was calculated for this relationship.

The ORL decreased from $1.97 \mathrm{~kg} \cdot \mathrm{VS} \cdot \mathrm{m}^{3} \cdot \mathrm{d}$ [RR $\left.40 \% ; 10 \mathrm{~m}^{3} \cdot \mathrm{RA} / \mathrm{d}\right]$ to $1.09 \mathrm{~kg} \cdot \mathrm{VS} \cdot \mathrm{m}^{3} \cdot \mathrm{d}$ [RR $27 \%$; $5.5 \mathrm{~m}^{3} \cdot \mathrm{RA} / \mathrm{d}$ ], and the HRT increased by $22 \%$ from an average of $4.21 \mathrm{~d}$ to $5.13 \mathrm{~d}$ (Figure 2).

The reduction in the RA caused significant variations amongst the test setups in terms of the OLR and the HRT, in contrast to other studies where the recirculation of the liquid fraction of the digestate did not lead to significant differences [27].

In comparison to other investigations, the HRT at a RR $40 \%$ (RA of $10 \mathrm{~m}^{3} / \mathrm{d}$ ) is slightly higher than the recommendations made based on their results. An HRT of $3 \mathrm{~d}$ has been suggested [21], and Chen et al. [28] determined an efficient and smooth operation of a biogas system using an HRT of $1.8 \mathrm{~d}$ (OLR $12.5 \mathrm{~kg} / \mathrm{m}^{3} /$ day). In contrast to the HRT, the OLR of Chen et al. is approximately 10 times higher than that of this investigation (Figure 3). 


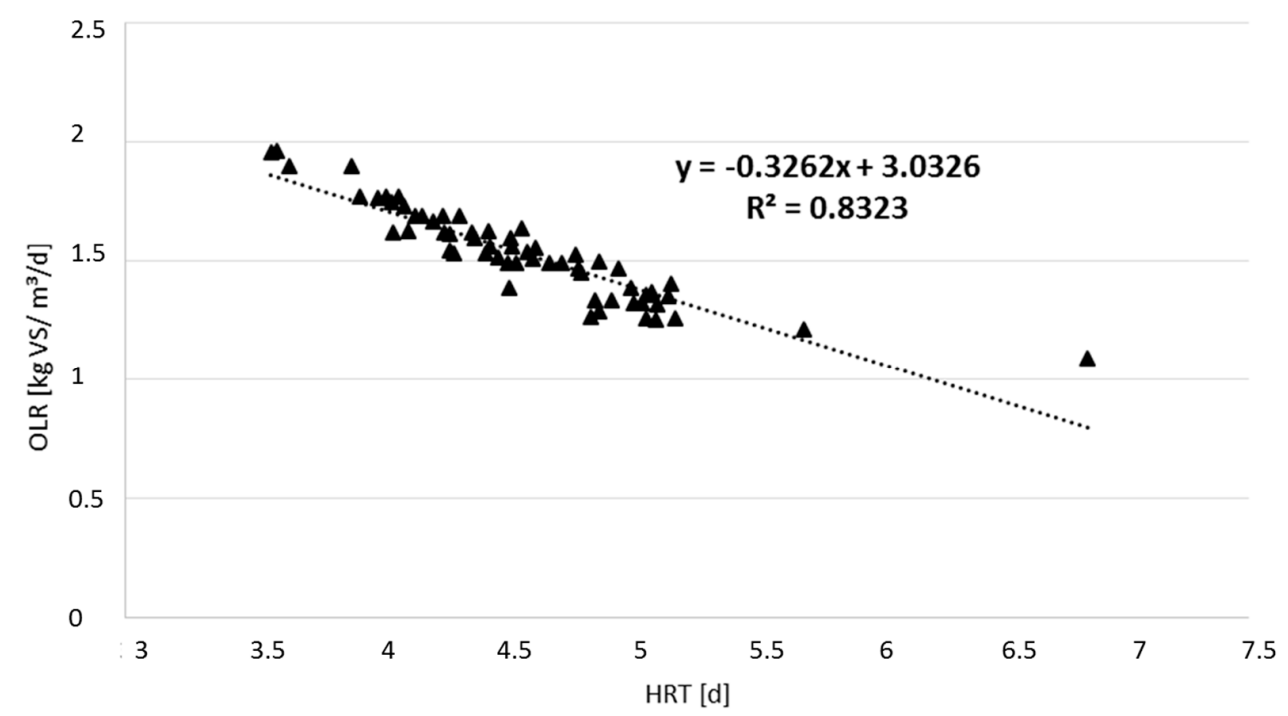

Figure 2. Linear regression of the OLR and the HRT $(\mathrm{R}=-0.912 ; p<0.05)$.

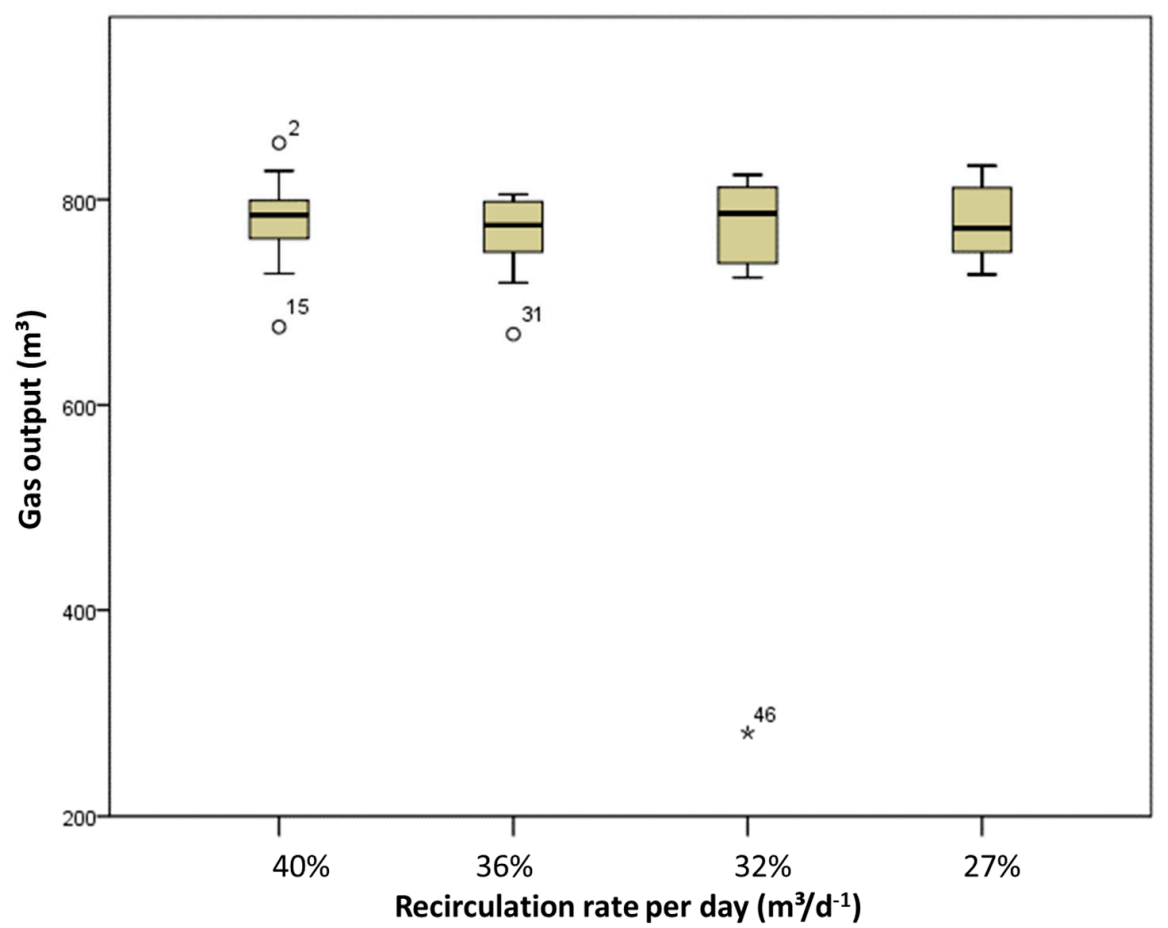

Figure 3. Gas output as a function of recirculation rate $(p<0.05)$.

In contrast to the technical parameters OLR and HRT, the differences in terms of efficiency, gas output $\left(\mathrm{m}^{3} / \mathrm{d}\right)$ (Figure 3 ) and energy output $(\mathrm{kWh} / \mathrm{d}$ ) (Figure 4 ) were not pronounced.

The boxplots in Figure 3 (also in Figures 4 and 5) describe the terms between the 25\% and 75\% percentile. The black line in the middle of the boxplots defines the median.

The lines above and below the boxplots show the highest as well as the lowest values measured. Values that were categorized as statistical outliers are signified with circles. In Figure 4 also an extreme value can be seen, marked with a little star.

At a RR $40 \%$ (RA of $10 \mathrm{~m}^{3} / \mathrm{d}$ ), the gas output is $779 \mathrm{~m}^{3} / \mathrm{d}(\sigma= \pm 34.17)$, amounting to $733 \mathrm{~m}^{3} / \mathrm{d}$ $(\sigma= \pm 153.75)$ on average at an $\mathrm{RA}$ of $7 \mathrm{~m}^{3} / \mathrm{d}$, with a high standard deviation. At the lowest rate $\left(5.5 \mathrm{~m}^{3} / \mathrm{d}\right)$, the gas output is almost as high as that at the first RR Step $\left(40 \%\right.$; RA $\left.10 \mathrm{~m}^{3} / \mathrm{d}\right)$. 
The energy output exhibits the same trend. First, with a RR 40\% (RA of $10 \mathrm{~m}^{3} / \mathrm{d}$ ), an average energy output of $1.789 \mathrm{kWh} / \mathrm{d}(\sigma= \pm 80.98 \mathrm{kWh} / \mathrm{d})$ was measured. This amount decreases to $1.736 \mathrm{kWh} / \mathrm{d}(\sigma= \pm 162.62 \mathrm{kWh} / \mathrm{d})\left(\mathrm{RR} 32 \%\right.$; RA $\left.7 \mathrm{~m}^{3} / \mathrm{d}\right)$, and at a RR $27 \%$ (RA 5.5), it again obtains the current output value (Figure 4).

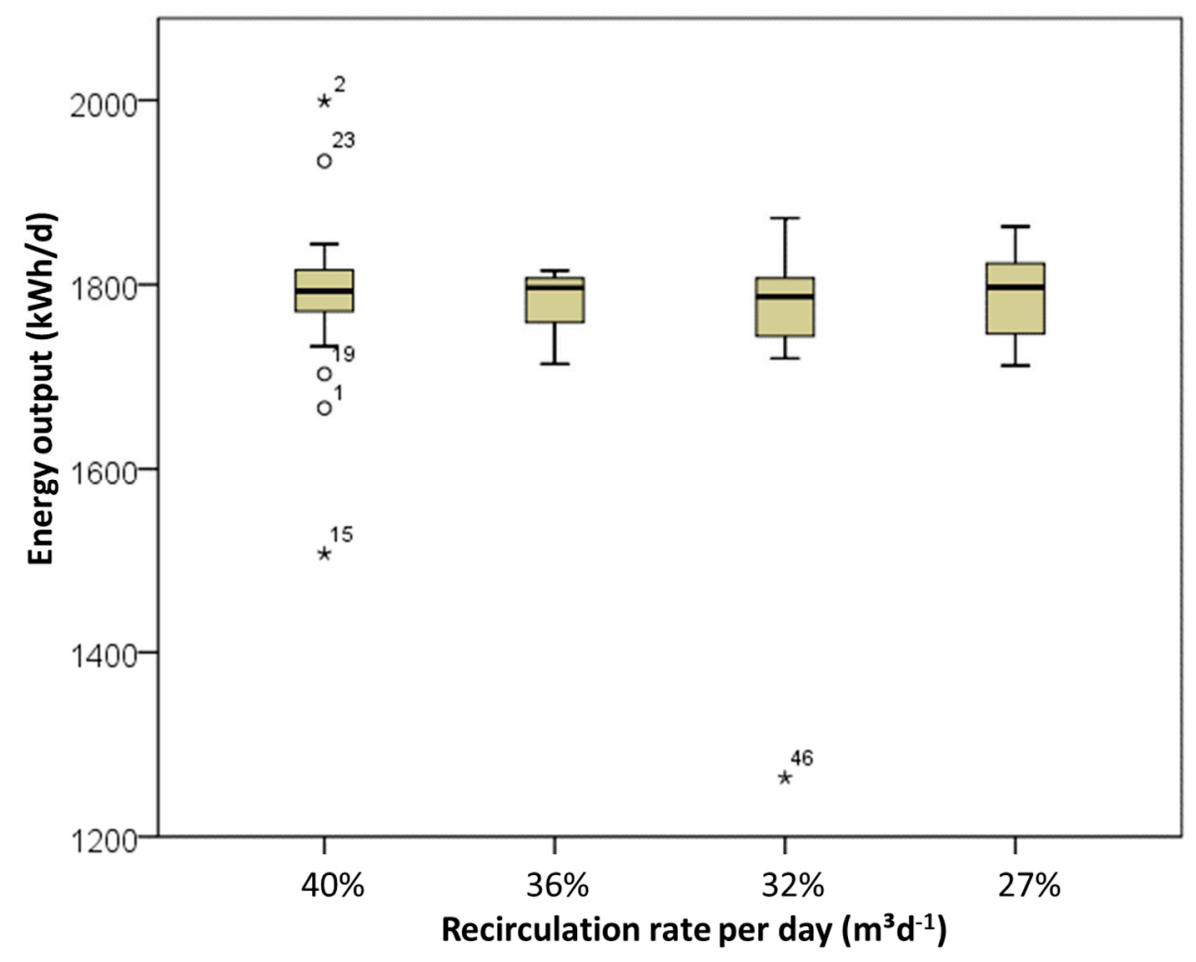

Figure 4. Energy output as a function of recirculation rate $(p<0.05)$.

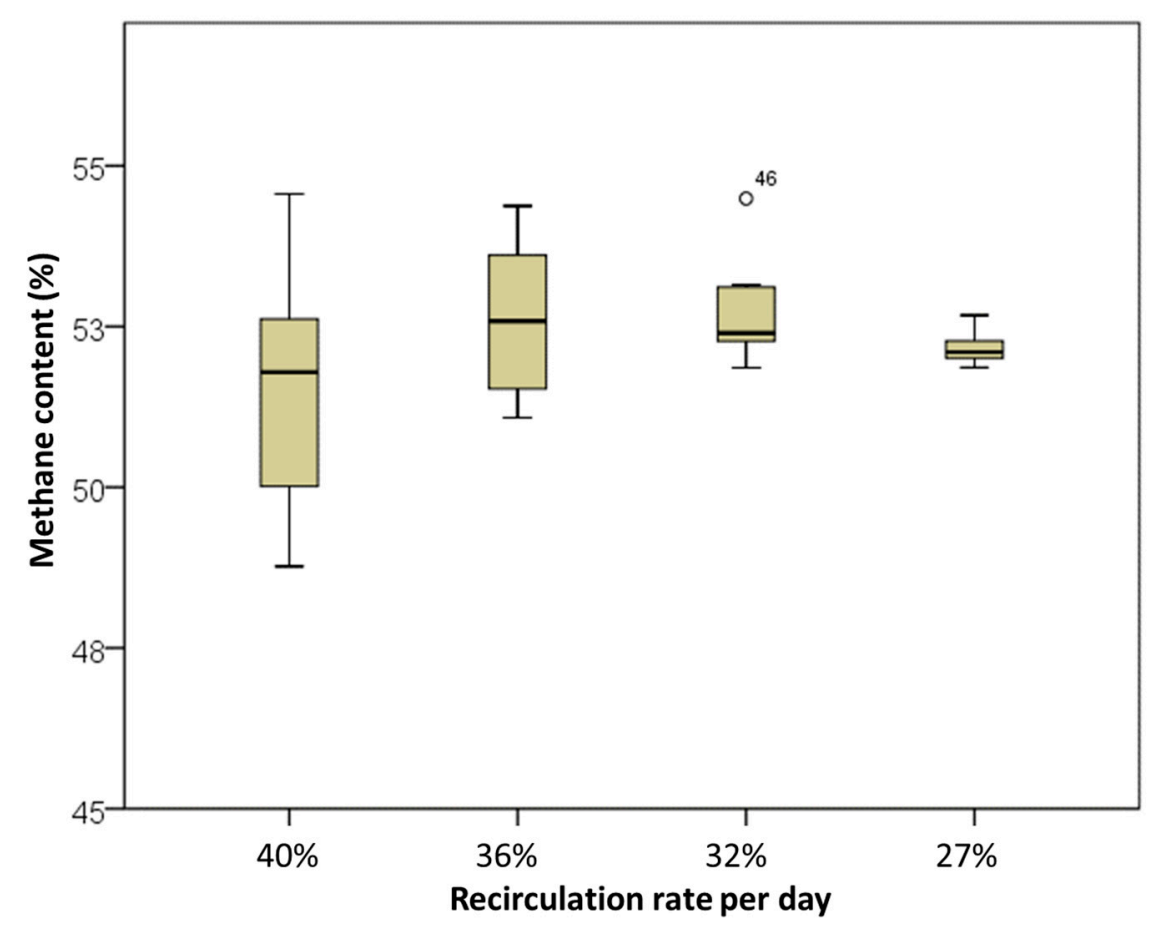

Figure 5. Methane content in the biogas as a function of recirculation rate $(p<0.05)$. 
Nevertheless, both parameters can be fixed so that the RA does not provoke a data break-out, even though there are significant differences amongst the four rates. In practice, it can be assumed that the RA has no major influence on efficiency and economic profit. In contrast, the measurements of the methane content in the biogas showed highly significant variations with the RA levels (Figure 5). At an RA of $8.5 \mathrm{~m}^{3} / \mathrm{d}$, the methane content reached its highest average level of $52.6 \%(\sigma= \pm 1.18 \%)$. In this example, the OLR is $1.52 \mathrm{~kg} \cdot \mathrm{VS} / \mathrm{m}^{3} / \mathrm{d}$, and the HRT is $4.65 \mathrm{~d}$.

The studies by Babaee and Shayegan [29] and Estevez et al. [30] found the highest methane content at an OLR of approximately 1.4 to $1.5 \mathrm{~kg} \cdot \mathrm{VS} / \mathrm{m}^{3} / \mathrm{d}$ and are therefore comparable to our results.

The lowest methane content $(51.5 \%)$ was measured at a RR $40 \%\left(\mathrm{RA} 10 \mathrm{~m}^{3} / \mathrm{d}\right)$. The OLR here was at a maximum of $1.67 \mathrm{~kg} \cdot \mathrm{VS} / \mathrm{m}^{3} / \mathrm{d}$, and the HRT was $4.21 \mathrm{~d}$. In addition, the spread of the values decreased with decreased RA. This results in a more secure fermentation process, and the actual RR, defined as best practice $\left(40 \%\right.$; RA $\left.10 \mathrm{~m}^{3} / \mathrm{d}\right)$, should be reduced.

To examine the possible causes, data of the various biological parameters should be combined with data of the technical parameters. In Figure 6, the dry matter (DM) and organic dry matter (oDM) contents are presented for all RRs. A decreased substrate input causes the DM and oDM contents of the biogas substrate to decrease. As mentioned in Table 1, the ratio of the SR to the ST is high, namely, one third of the substrate used in fermentation is based on the recirculated biogas substrate. With the lowest RR, 13\% less substrate input was measured. With higher DM and oDM contents, the recirculated substrate was found not only to dilute the mature but also to be an important source of fermentation material.
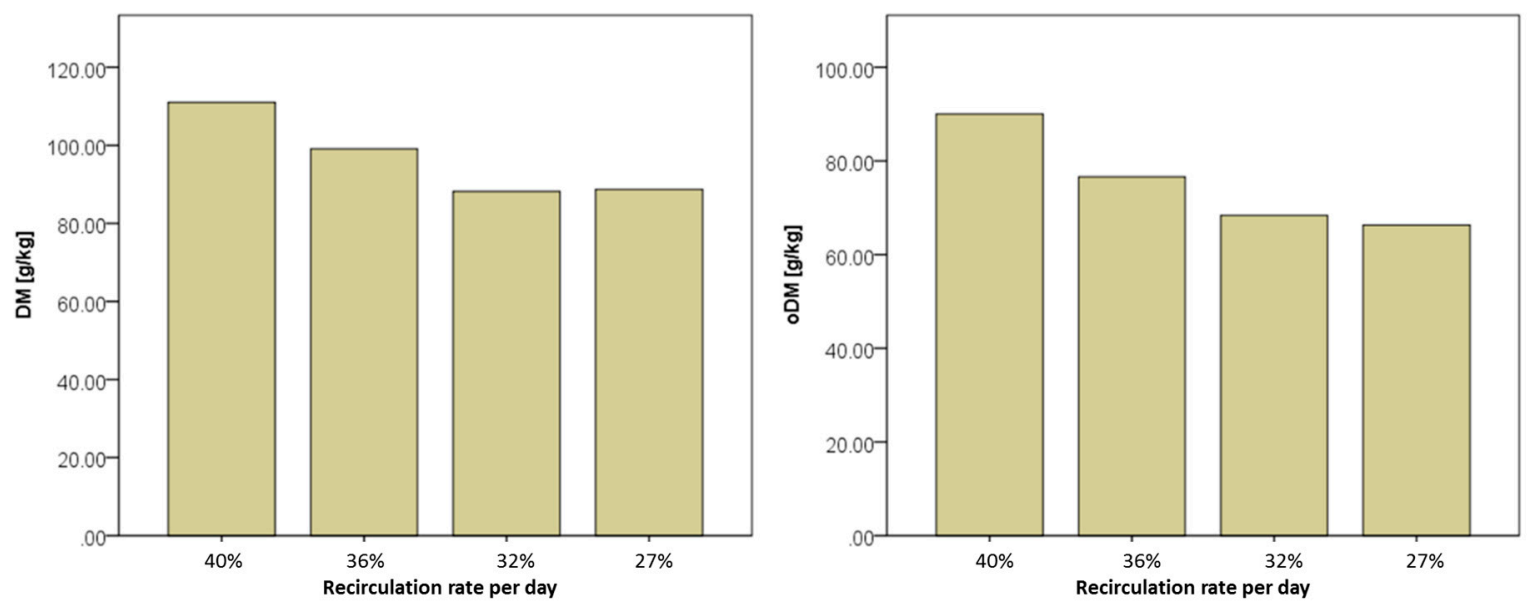

Figure 6. Dry matter (DM) and organic dry matter (oDM) contents in the biogas substrate as a function of recirculation rate.

Further examining the fermentation of the organic material, the biogas process can be separated into four main stages. During acidogenesis and acetogenesis (the second and third stage), organic acids were the main end products and were used as raw materials for the last stage, methanogenesis, where methane is produced as an end product.

During this investigation, we demonstrated that an increasing RR results in lower concentrations of various organic acids (Figure 7) and leads to a positive effect on the acid concentration as well as in the pH-regulation. The acetic-acid content varies between 3.5 and $1.2 \mathrm{~g} / \mathrm{L}$ and is $50 \%$ lower at a RR of $27 \%$ (RA $5.5 \mathrm{~m}^{3} / \mathrm{d}$ ) compared to a RR of $40 \%$ (RA $10.0 \mathrm{~m}^{3} / \mathrm{d}$ ).

The acetic acid content of the biogas fermentation should be $<3.0 \mathrm{~g} / \mathrm{L}$, the propionic acid content should be $<0.6 \mathrm{~g} / \mathrm{L}$, and the butyric acid content should be $<0.05 \mathrm{~g} / \mathrm{L}$ [31]. In contrast, Gourdon and Vermande [32] claimed that a propionic acid content of up to $6.0 \mathrm{~g} / \mathrm{L}$ has no toxic effect on the methanogenesis based on their investigation. Overall, the propionic acid content should not be higher 
than $50 \%$ of the acetic acid content. This is justified by the fact that propionic acid cannot be recovered by methanogens. Otherwise, a malfunction in the biogas process could result [31].
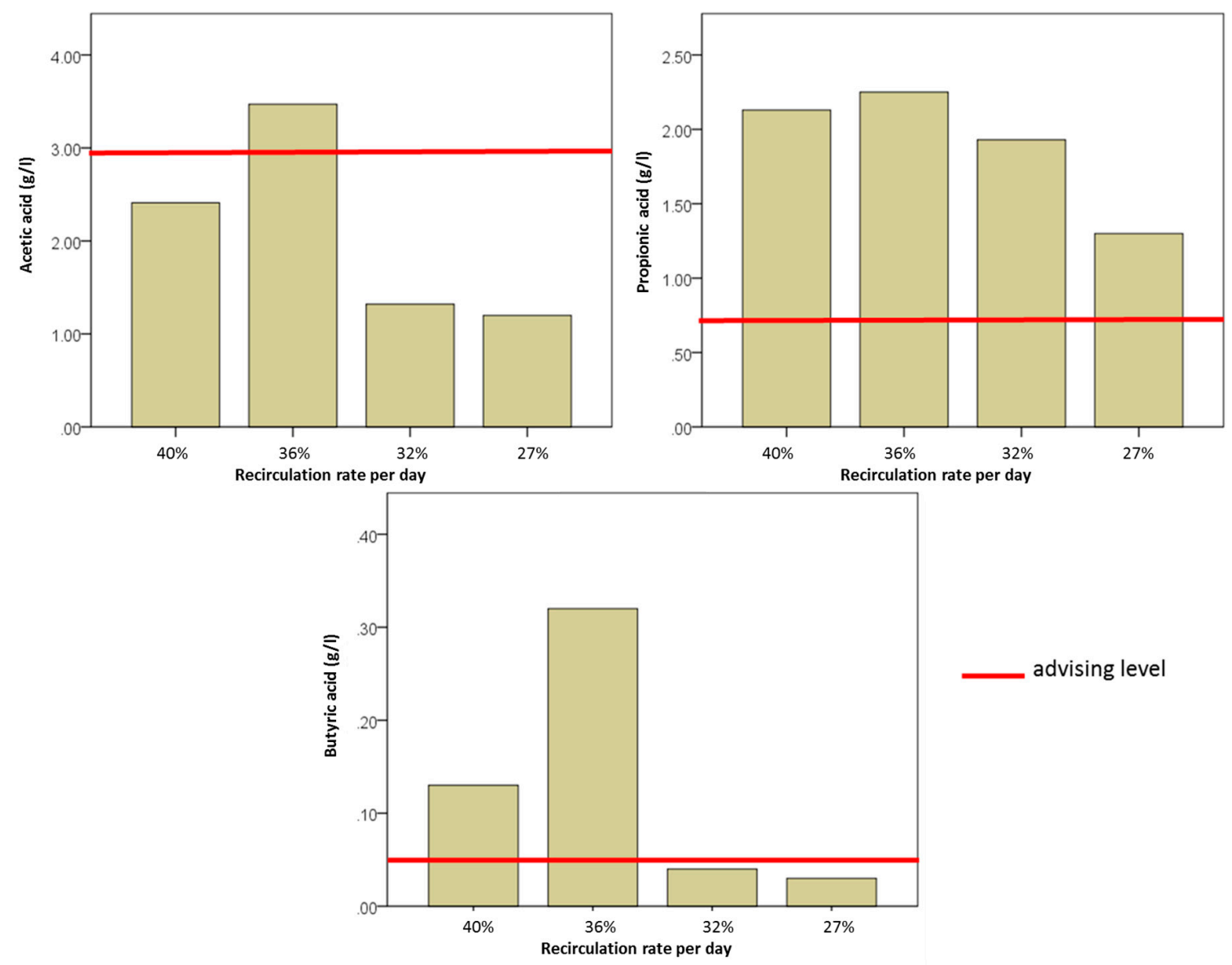

_ advising level

Figure 7. Acetic, propionic and butyric acid contents of the biogas substrate as a function of recirculation rate.

The propionic acid concentration decreases by $60 \%$ from $2.13 \mathrm{~g} / \mathrm{L}$ (RR $40 \%$ ) to $1.3 \mathrm{~g} / \mathrm{L}$ (RR $27 \%$ ), and the butyric acid content decreases by $23 \%$ from $0.13 \mathrm{~g} / \mathrm{L}$ (RR $40 \%$ ) to $0.03 \mathrm{~g} / \mathrm{L}$ (RR $27 \%$ ). When comparing the propionic acid concentration to the acetic acid content, the $50 \%$ difference proposed by KTBL [31] could not be observed for every recirculation rate. The propionic acid content is almost equal to the acetic acid concentration, and for RRs of $32 \%$ and $27 \%$, the content is even higher. Only at a RR of $36 \%$ is the optimal relationship obtained. As a consequence, the methanogenesis process could be disturbed. Munk et al. [16] stated that acidification reactions at low OLRs may occur. This is in line with our own results and the observed imbalance of the acetic acid concentration with the propionic acid content. However, it should be noted that from the beginning, at a RR of $40 \%$, the acetic acid and propionic acid contents are imbalanced. The results of other authors demonstrate that a positive effect can be achieved based on the RR via dilution, the lack of volatile fatty acid inhibition and better $\mathrm{pH}$ regulation [21].

Exceeding of the optimal acid concentration for fermentation is also observed based on the measured $\mathrm{pH}$ values for all four RAs. Normally, the optimal $\mathrm{pH}$ value for thermophilic biogas plants is approximately 6.5 to 7.5 [8,33]. During this investigation, the $\mathrm{pH}$ value of the biogas substrate was approximately 7.9 to 8.1 (Figure 8). There was no significant decrease or increase in $\mathrm{pH}$ observed based on changes in the RA. Zuo et al. [18] recognised that the $\mathrm{pH}$ decreases with increasing OLR. This observation could not be confirmed by this investigation. Generally, it should be noted that the 
measured $\mathrm{pH}$ is above the optimal value, with a tendency to be basic. Moreover, the anticipated effect of the dilution of the substrate within the first fermenter with increased RR was not observed.

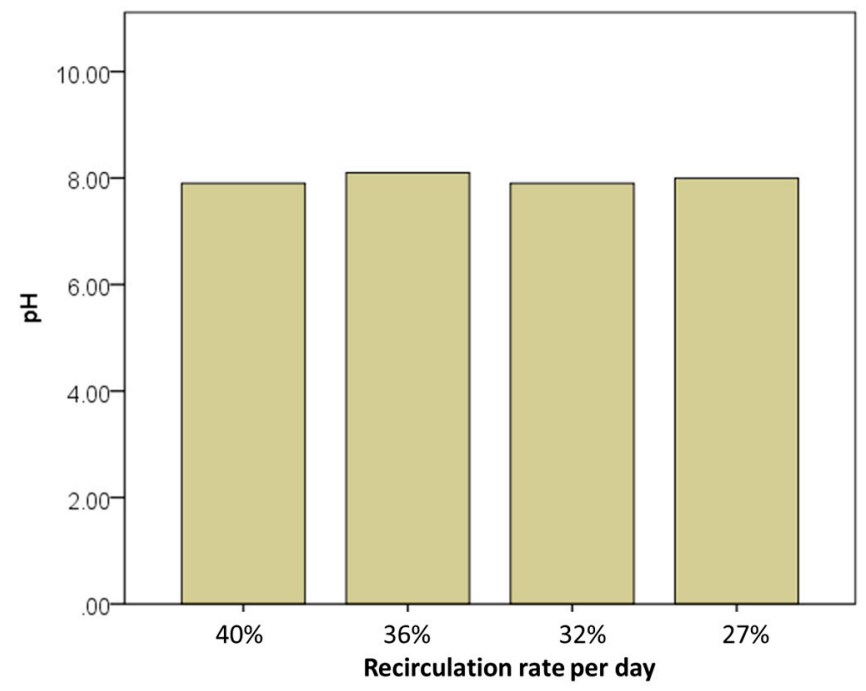

Figure 8. $\mathrm{pH}$ as a function of recirculation rate.

Recalling the positive trend followed by the methane concentration of the biogas resulting from the decreased RR, it should be noted that a high acid concentration did not have a negative effect on the methane yield of the investigated biogas plant. However, with the decreasing acid content approaching the optimal range and the required ratio of acetic acid to propionic acid, the fermentation process was observed to have stabilized based on the increasing methane content and smaller variations in the concentrations.

The second question concerning the use of the RR as a control mechanism could not be clearly answered based on the results generated using the various parameters. The RR was found to have a significant influence on the main technical as well as biological parameters. The concentrations of the most important acids decreased during fermentation at lower recirculation rates. Thus, the RR can be used to control the acid contents within a certain framework without the use of other critical additives.

\section{Conclusions}

Starting with a RR of $40 \%$, which is the standard recommendation ("best practice"), the RA was decreased by $1.5 \mathrm{~m}^{3}$ every ten days for a total of four times. A significant change in OLR and HRT could be observed in addition to the anticipated negative correlation of OLR to HRT. However, the use of the RR as a control mechanism for biogas parameters cannot be recommended.

Because of the decreased RR, a stabilisation of the fermentation process could be obtained, and an increasing methane yield and smaller variations in the measured terms were observed. The acid concentrations were analysed as a possible reason for these results. During this investigation, the acid concentrations were higher than the optimal levels. An approximation of the optimum concentration could be obtained with decreased recirculation.

Using a combination of the measured parameters (OLR, HRT, methane content, acid concentration) and a comparison based on varying the RR, the proposed so-called "best practice" could not be confirmed with our results. A RR of $27 \%$ provided the best efficiency for this investigated biogas plant.

Acknowledgments: This work was financially supported by Fachagentur Nachwachsende Rohstoffe e.V. (FNR). The authors acknowledge Stefan Bleser and Benedikt Humpert for their experimental and technical support.

Author Contributions: All authors contributed equally in the creation of this paper.

Conflicts of Interest: The authors declare no conflict of interest. 


\section{Nomenclature}

$\begin{array}{ll}c & \text { concentration of organic matter (volatile solids) }(\% \mathrm{VS}) \\ \text { HRT } & \text { hydraulic retention time } \\ \text { LU } & \text { livestock unit }(500 \mathrm{~kg} \text { body weight }) \\ \dot{m} & \text { substrate added per unit of time }(\mathrm{kg} / \mathrm{d}) \\ \text { oDM } & \text { organic dry matter } \\ \text { OLR } & \text { organic loading rate } \\ \text { RA } & \text { recirculation amount } \\ \dot{V} & \text { volume of substrate added daily } \\ V_{R} & \text { reactor volume } \mathrm{m}^{3} \\ \text { VS } & \text { volatile solids or organic dry matter }\end{array}$

\section{References}

1. Asam, Z.; Poulsen, T.G.; Nizami, A.; Rafique, R.; Kiely, G.; Murphy, J.D. How can we improve biomethane production per unit of feedstock in biogas plants? Appl. Energy 2011, 88, 2013-2018. [CrossRef]

2. Chynoweth, D.P.; Owens, J.M.; Legrand, R. Renewable methane from anaerobic digestion of biomass. Renew. Energy 2001, 22, 1-8. [CrossRef]

3. Esposito, G.; Frunzo, L.; Panico, A.; Pirozzi, F. Enhanced bio-methane production from co-digestion of different organic wastes. Environ. Technol. 2012, 33, 2733-2740. [CrossRef] [PubMed]

4. Buhr, H.O.; Andrews, J.F. The thermophilic anaerobic digestion process. Water Res. 1977, 11, $129-143$. [CrossRef]

5. Ahring, B.K. Methanogenesis in thermophilic biogas reactors. Antonie Van Leeuwenhoek 1995, 67, 91-102. [CrossRef] [PubMed]

6. Pap, B.; Györkei, Á.; Boboescu, I.Z.; Nagy, I.K.; Bíró, T.; Kondorosi, É.; Maróti, G. Temperature-dependent transformation of biogas-producing microbial communities points to the increased importance of hydrogenotrophic methanogenesis under thermophilic operation. Bioresour. Technol. 2015, 177, 375-380. [CrossRef] [PubMed]

7. Hartmann, H.; Ahring, B.K. Strategies for the anaerobic digestion of the organic fraction of municipal solid waste: An overview. Water Sci. Technol. 2006, 53, 7-22. [CrossRef] [PubMed]

8. Ward, A.J.; Hobbs, P.J.; Holliman, P.J.; Jones, D.L. Optimisation of the anaerobic digestion of agricultural resources. Bioresour. Technol. 2008, 99, 7928-7940. [CrossRef] [PubMed]

9. Panico, A.; D'Antonio, G.; Esposito, G.; Frunzo, L.; Iodice, P.; Pirozzi, F. The effect of substrate-bulk interaction on hydrolysis modelling in anaerobic digestion process. Sustainability 2014, 6, 8348-8363. [CrossRef]

10. Yadvika, S.; Santosh, T.R.; Sreekrishnan, T.R.; Kohli, S.; Rana, V. Enhancement of biogas production from solid substrates using different techniques-A review. Bioresour. Technol. 2004, 95, 1-10. [CrossRef] [PubMed]

11. Mahmoud, N.; Zeeman, G.; Gijzen, H.; Lettinga, G. Solids removal in upflow anaerobic reactors, a review. Bioresour. Technol. 2003, 90, 1-9. [CrossRef]

12. Michele, P.; Giuliana, D.; Carlo, M.; Sergio, S.; Fabrizio, A. Optimization of solid state anaerobic digestion of the OFMSW by digestate recirculation: A new approach. Waste Manag. 2015, 35, 111-118. [CrossRef] [PubMed]

13. Nordberg, Å.; Jarvis, A.; Stenberg, B.; Mathisen, B.; Svensson, B.H. Anaerobic digestion of alfalfa silage with recirculation of process liquid. Bioresour. Technol. 2007, 98, 104-111. [CrossRef] [PubMed]

14. Bories, A.; Raynal, J.; Bazile, F. Anaerobic digestion of high-strength distillery wastewater (cane molasses stillage) in a fixed-film reactor. Biol. Wastes 1988, 23, 251-267. [CrossRef]

15. Rincón, B.; Borja, R.; González, J.M.; Portillo, M.C.; Sáiz-Jiménez, C. Influence of organic loading rate and hydraulic retention time on the performance, stability and microbial communities of one-stage anaerobic digestion of two-phase olive mill solid residue. Biochem. Eng. J. 2008, 40, 253-261. [CrossRef]

16. Munk, B.; Bauer, C.; Gronauer, A.; Lebuhn, M. Population dynamics of methanogens during acidification of biogas fermenters fed with maize silage. Eng. Life Sci. 2010, 10, 496-508. [CrossRef]

17. Estevez, M.M.; Sapci, Z.; Linjordet, R.; Schnürer, A.; Morken, J. Semi-continuous anaerobic co-digestion of cow manure and steam-exploded Salix with recirculation of liquid digestate. J. Environ. Manag. 2014, 136, 9-15. [CrossRef] [PubMed] 
18. Zuo, Z.; Wu, S.; Zhang, W.; Dong, R. Performance of two-stage vegetable waste anaerobic digestion depending on varying recirculation rates. Bioresour. Technol. 2014, 162, 266-272. [CrossRef] [PubMed]

19. Jarvis, S.; Nordberg, A.; Mathisen, B.; Svensson, B.H. Stimulation of conversion rates and bacterial activity in a silage-fed two-phase biogas process by initiating liquid recirculation. Antonie Van Leeuwenhoek 1995, 68, 317-327. [CrossRef] [PubMed]

20. Baader, W.; Braunschweig, F.R. Performance of completely filled vertical through-flow anaerobic digester. In Alternative Sources of Energy for Agriculture; FFTC Book Series 28; FFTC: Taipei, Taiwan, 1985; pp. 51-65.

21. Zuo, Z.; Wu, S.; Zhang, W.; Dong, R. Effects of organic loading rate and effluent recirculation on the performance of two-stage anaerobic digestion of vegetable waste. Bioresour. Technol. 2013, 146, 556-561. [CrossRef] [PubMed]

22. Aslanzadeh, S.; Rajendran, K.; Jeihanipour, A.; Taherzadeh, M. The effect of effluent recirculation in a semi-continuous two-stage anaerobic digestion system. Energies 2013, 6, 2966-2981. [CrossRef]

23. British Standards Institution. EN 12176:1998: Characterization of Sludge. Determination of pH Value; 13.030.20; BSI: London, UK, 1998.

24. British Standards Institution. EN 12880:2000: Characterization of Sludges. Determination of Dry Residue and Water Content; 13.030.20; BSI: London, UK, 2000.

25. British Standards Institution. EN 12879:2000: Characterization of Sludges. Determination of the Loss of Ignition of Dry Mass; 13.030.20; BSI: London, UK, 2000.

26. Al Seadi, T.; Rutz, D.; Prassl, H.; Köttner, M.; Finsterwalder, T.; Volk, S.; Janssen, R. Biogas Handbook; University of Southern Denmark: Esbjerg, Denmark, 2008.

27. Hu, Y.; Shen, F.; Yuan, H.; Zou, D.; Pang, Y.; Liu, Y.; Zhu, B.; Chufo, W.A.; Jaffar, M.; Li, X. Influence of recirculation of liquid fraction of the digestate (LFD) on maize stover anaerobic digestion. Biosyst. Eng. 2014, 127, 189-196. [CrossRef]

28. Chen, Y.; Rößler, B.; Zielonka, S.; Wonneberger, A.; Lemmer, A. Effects of organic loading rate on the performance of a pressurized anaerobic filter in two-phase anaerobic digestion. Energies 2014, 7, 736-750. [CrossRef]

29. Babaee, A.; Shayegan, J. Effect of organic loading rates (OLR) on production of methane from anaerobic digestion of vegetables waste. In Proceedings of the World Renewable Energy Congress, Linköping, Sweden, 8-13 May 2011.

30. Estevez, M.M.; Linjordet, R.; Morken, J. Organic loading rate effect on anaerobic digestion: Case study on co digestion of lignocellulosic pre-treated material with cow manure. In Proceedings of the International Conference of Agricultural Engineering, Valencia, Spain, 8-12 July 2012.

31. Kuratorium für Technik und Bauwesen in der Landwirtschaft (KTBL). Faustzahlen Biogas: 3. Ausgabe, Tabellenwerk, Kuratorium für Technik und Bauwesen in der Landwirtschaft; Kuratorium für Technik und Bauwesen in der Landwirtschaft: Darmstadt, Germany, 2013.

32. Gourdon, R.; Vermande, P. Effects of propionic acid concentration on anaerobic digestion of pig manure. Biomass 1987, 13, 1-12. [CrossRef]

33. Zhang, T.; Mao, C.; Zhai, N.; Wang, X.; Yang, G. Influence of initial pH on thermophilic anaerobic co-digestion of swine manure and maize stalk. Waste Manag. 2015, 35, 119-126. [CrossRef] [PubMed]

(C) 2017 by the authors. Licensee MDPI, Basel, Switzerland. This article is an open access article distributed under the terms and conditions of the Creative Commons Attribution (CC BY) license (http:/ / creativecommons.org/licenses/by/4.0/). 